\title{
RESEARCH PARAMETERS OF ULTRASOUND PROCESSING EQUIPMENT DISPERSED IN TECHNOLOGICAL ENVIRONMENT
}

\author{
I. N. Bernyk \\ National Technical University of Ukraine "Kyiv Polytechnic Institute". Ukraine. \\ Speciality of article: 133 - industry engineering. \\ Corresponding authors: iryna_bernyk@i.ua.
}

Article history: Received - October 2019, Accepted-January 2020.

Bibl. 13, fig. 15, tabl. 0 .

Abstract. Effective use of ultrasound in specific manufacturing processes due to the effects of fluctuations in the environment, manifested in the physical and chemical effects and their interaction. The most successful is the use of ultrasound cavitation processing of liquid and liquid-dispersed environments, because they have effectively implemented the mechanism of sound wave energy concentration in low-density high energy density, which is caused by the formation, development and slamming cavitation bubbles. The research on the influence of cavitation on chemical processes in the liquid, the erosion effect of acoustic cavitation, acoustic cavitation the action on biological objects in nature and intensity acoustic noise accompanying cavitation, showed that methods for measuring parameters of acoustic field can be divided into direct and indirect. Direct methods directly measure the cavitation process parameters, such as measurement of pressure that occurs when slamming cavitation bubbles. For indirect methods determined by technological or physical effect of ultrasound cavitation. . The analysis of existing research found that the most promising method of measurement configuration and cavitation field intensity acoustic cavitation process is being implemented using hydrophones. Measurement of sound pressure values were made using measuring hydrophones based on piezoceramic, resulting in the covers piezoelement appear hydrophone potential difference, whose value is proportional to the sound pressure. Measuring the magnitude of the voltage proportional to the sound pressure, was made rms voltmeter values resulting measured voltage is proportional to the pressure not only sound, but also the intensity of ultrasound vibrations. The basic analytical dependences for determination of sound pressure, intensity ultrasound vibrations, radiation impedance made it possible to build a graph showing the cavitation processing technology environments. . Experimentally verified the identity of law ultrasound field distribution in the water and in the technological mix considering its extinction. Research resonant actuators installed emitters that provide quality cavitation treatment mixture is possible only at a specific distance from the radiation. Consideration of the conditions for the creation of technological equipment makes it possible to improve the parameters of cavitation processing of liquid-dispersed environments by minimizing energy costs.

Key words: research, parameter, equipment, technological environment.

\section{Introduction}

Modern treatment processes of technological environments of chemical, food, pharmaceutical and other processing industries are inextricably linked with energy use of different intensity ultrasound fields [1-3].

Ultrasound technology can intensify processes, increase the degree of utilization of raw materials, change the source material properties, and create new substances and environment, to ensure environmental safety and production [4-6].

Effective use of ultrasound technology in manufacturing processes due to specific effects of fluctuations in the environment, manifested in the physical and chemical effects and their interaction.

The most successful treatment is the use of liquid and liquid-disperse mediums because in them the phenomenon - Ultrasound cavitation is an effective mechanism for concentration of energy of sound waves in the low-density high energy density, which is caused by pulsations and cavitation bubbles slamming [8-11].

\section{Formulation of problem}

The emergence and development of ultrasound accoustic cavitation causes changes in the acoustic parameters of the liquid, which when echoed in turn influences the parameters of the process [12].

If cavitation is changing acoustic properties and there is distortion sound field.

Thus, the study of sound field configuration to optimize key indicators processes associated with the processing of liquid and liquid-disperse mediums that take place under the influence of acoustic cavitation. 


\section{Analysis of recent research results}

The measurement of the cavitation region can be made several ways: by the action of cavitation on chemical processes in the liquid [13]; erosive action of acoustic cavitation [14]; the action of acoustic cavitation on biological objects [15]; the nature and intensity of acoustic noise that accompanies Cavitation [16] and several others. With this method, measuring the parameters of the acoustic field conditionally divided into direct and indirect. Direct methods include methods in which directly measure the parameters of cavitation bubbles, such pressure that occurs when slamming cavitation bubbles. Indirect methods include those for which examines technological or physical effect of ultrasound cavitation. Consider in more detail the basic methods of measuring the parameters of cavitation field.

Ultrasound cavitation in liquids accompanied by sonoluminescence [17]. This intensity of light depends on the intensity of the cavitation process. Today there is no single theory that explains the phenomenon sonoluminescence but based on measuring the intensity of the generated light flux can assess configuration cavitation field intensity and the cavitation process in it. Measuring luminous flux is carried out using photoelectric multiplier as the light output is very weak.

The disadvantage of this method is the fact that measurements can only be made in a completely dark room, denying access external illumination. This actually may get only two-dimensional picture of the cavitation field. Due to the fact that the photoelectron multiplier has dimensions that are equal wavelength in the liquid, measuring the depth of the process leading to the volume of material misstatement of the acoustic field configurations, respectively, and cavitation field. It should also be noted that the measure may only be made in optically transparent liquids. In view of the above shortcomings, named method of measuring the intensity of the cavitation process and measurement of cavitation region has not received distribution.

In [18] the significant influence of ultrasound cavitation on biological objects. Under the influence of cavitation bubbles slamming in phase is complete or partial destruction of microorganisms and bacteria. The number of inactivated organisms depends on processing time and intensity ultrasound vibrations. Given that, you can evaluate a field of cavitation effect, but given method does not assess the configuration of the cavitation field.

Chemical methods of measuring the intensity of the cavitation process parameters and cavitation region [19] based on the fact that under the influence of ultrasound cavitation is number of specific chemical reactions that are impossible or occur too slowly in normal conditions. As an example, the chemical decomposition reaction of potassium iodide with the release of free iodine and starch solution color. The degree of coloration of iodine can be estimated by optical methods. The disadvantages of chemical methods should include the fact that they can not be used in those cases where technological environment are objects that are able to enter into chemical reaction with reagents indicators. Also, in general, difficult to visualize chemical methods of hardware and their use does not allow use of automation in manufacturing processes, as chemical methods have not acquired a significant spread.

It is known that under the influence of powerful ultrasound vibrations and acoustic cavitation degassing is irradiated fluid [20]. By the degree of decontamination or volume of gas released, you can judge the intensity of cavitation processes. However, these methods are complicated by difficulties with compliance with the initial conditions and the technical difficulties associated with the need to measure the volume of gas released.

The above methods give an integrated assessment of cavitation action and not to judge the configuration cavitation field.

There is a change of ultrasound cavitation process fluid volume due to the formation of cavitation bubbles [21]. Thus the change in volume can judge the amount of bubbles, but it does not provide configuration information in the cavitation field.

A perfect method is based on the use sonocapillary effect [14]. Sonocapillary effect - is an abnormal elevation of the capillary liquid under acoustic cavitation. By raising the height of the liquid the intensity of cavitation can be judged at the point of measurement. These methods can estimate not only the intensity of the cavitation process at the point of measurement, but also to get configuration information in the cavitation field. The disadvantages of this method include the complexity and ambiguity of measurement difficulties associated with measuring complex hardware implementation.

Look for methods that are based on cavitation erosion activity area. These include the method of sample contamination [22] and the method of erosion tests [23, 24].

The method of sample contamination places a small sample of drawing on a coating which has a low adhesion to the surface, in the cavitation zone. The decrease in mass of the sample, results in the destruction of a layer of pollution which can judge the intensity of cavitation processes and build configuration cavitation field in the processing volume. The disadvantage of the method includes its bulkiness and metrological complexity associated with the need to measure small changes in mass of the sample.

Erosion test method is the destruction of the samples with cavitation unstable material under acoustic cavitation for a fixed period of time. Assessment cavitation intensity exercise or weight reduction of the sample, or the reduction of its area. The most widespread use to achieve that goal became to use aluminum foil. This decrease in the area of the foil is easily measured by optical methods. Despite its simplicity, the method has a major drawback damaged areas foil is not involved in the demolition, which makes a significant difference metrology. Also ideal method is not suitable for process volumes with low cavitation processes through a small degree of destruction of the test sample. Also, if a sample of large area significantly disrupted the interference pattern in the technological scope, leading to a gradual change in form cavitation field in the measurement.

The most promising methods of measurement configuration and cavitation field intensity accoustic cavitation process applies (using hydrophones) [25]. The output value of the hydrophone generated voltage 
(charge), which is proportional to the sound pressure. Mutual correspondence between electrical voltage and sound pressure can be determined by standard methods of reciprocity.

During the measurement of small sound pressure, cavitation mode underdeveloped or precavitational mode, you can configure cavitation field, when moving hydrophone technology in volume. Measure the value of the voltage, proportional to the sound pressure by using ac voltmeter. By analyzing the spectral composition of the signal hydrophones can indirectly judge the intensity of cavitation processes.

The physical dimensions of hydrophones can be minimized, which allows to reduce the degree of distortion of the sound field when you use it. The method allows us to investigate how the shape of the sound field, and to assess the intensity of cavitation processes.

From the analysis of research methods configuration cavitation field intensity and the cavitation process implies that measurements using hydrophones are the most promising.

\section{Purpose of research}

Setting ultrasound liquid processing equipment disperse technological environment.

\section{Results of research}

Measuring the value of sound pressure can be achieved by means of measuring hydrophones based on piezoceramic. During the reception mode on the covers of hydrophones piezoelement there is a potential difference, whose value is proportional to the sound pressure. Calibration of hydrophones can be done by various methods, such as reciprocity standard method [25]. In particular, hydrophones used in measurements (Fig. 1) was sensitivity $M=7,9 \cdot 10^{-5} \quad B / \Pi a$.

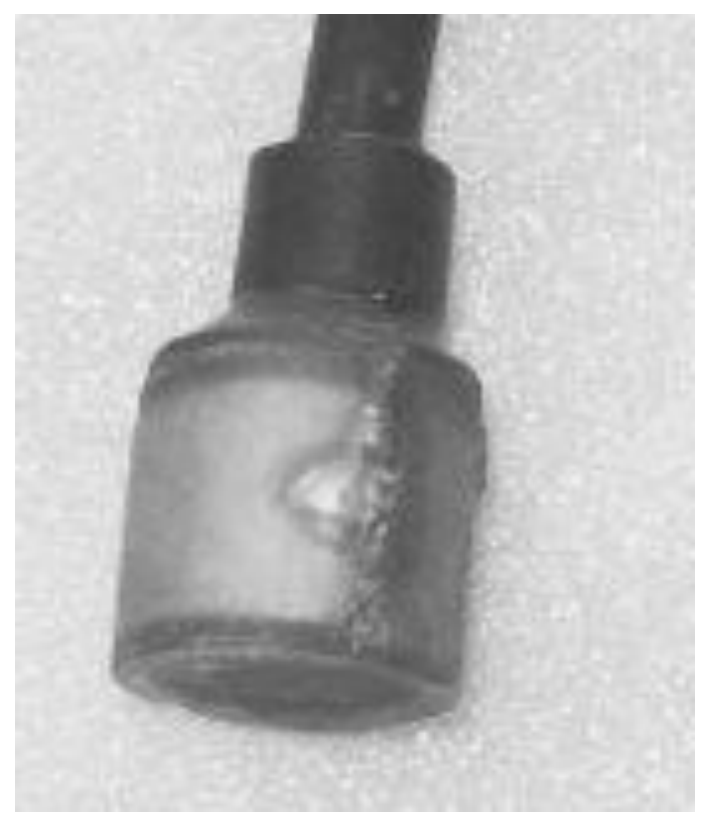

Fig. 1. Measuring hydrophone based on
Note that measure the voltage proportional to the sound pressure can be achieved in various ways, including: a peak voltmeter, voltmeter average value and rms voltmeter. This measurement different ways lead to different results. This is due to the fact that the appearance of cavitation phenomena form the voltage on the hydrophone will differ significantly from the harmonic (Fig. 2).

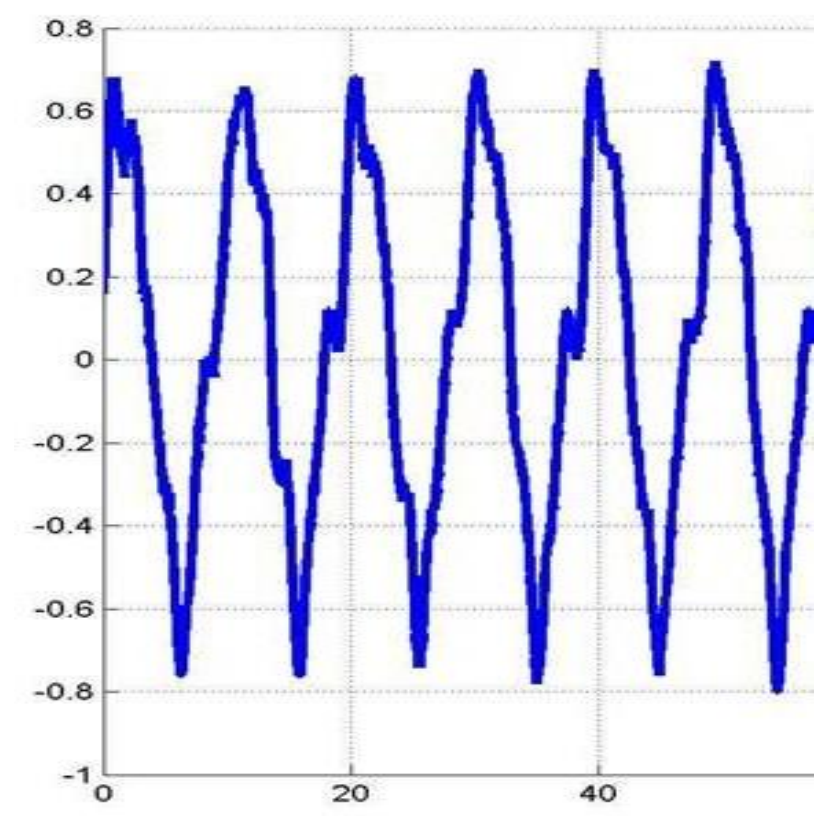

Fig. 2. Form voltage at the hydrophones in the event of cavitation.

Based on the fact that the shape of the measured voltage differs significantly from the harmonious formula, and it is advisable to measure the rms voltmeter V3-57 values. This measured voltage is proportional to the pressure not only sound, but also the intensity of ultrasound vibrations.

The spread of ultrasound in liquid accompanied by the absorption of energy in the technological volume, which reduces the peak value of sound pressure with distance from the source of ultrasound vibrations. Most [26] assessed not reduce the amplitude of sound pressure and intensity ultrasound vibrations change:

$$
I(x)=I(0) \cdot e^{-2 \cdot \alpha \cdot x},
$$

where: $I(x)$ - intensity ultrasound vibrations at coordinates $x ; I(0)$ - intensity ultrasound vibrations at the origin; $\alpha$ - ultrasound attenuation coefficient.

Therefore, ultrasound attenuation coefficient can be calculated by measuring according to the formula:

$$
\alpha=\frac{1}{2 \cdot\left(x_{2}-x_{1}\right)} \cdot \ln \left(\frac{I_{1}}{I_{2}}\right),
$$

where: $x_{2}$ and $x_{1}$-coordinates measurements; $I_{1}$ and $I_{2}$ - intensity ultrasound vibrations in the respective measurement points.

The intensity ultrasound vibrations associated with the amplitude of the sound pressure ratio: piezoceramic. 


$$
I=\frac{P^{2}}{2 \cdot \rho \cdot c},
$$

where: $P$ - amplitude sound pressure; $\rho$ - density; $c-$ speed of sound.

Assuming that the change in density and speed of sound was dependent on the value of sound pressure (which is true for precavitational mode and mode poorly developed cavitation), dependence (2) can be written as:

$$
\alpha \approx \frac{1}{2 \cdot\left(x_{2}-x_{1}\right)} \cdot \ln \left(\frac{P_{1}}{P_{2}}\right)^{2},
$$

where:

$$
\alpha=\frac{1}{\left(x_{2}-x_{1}\right)} \cdot \ln \left(\frac{P_{1}}{P_{2}}\right) .
$$

Turning on the values of sound pressure to voltage at the terminals of hydrophones, we get the relationship:

$$
\alpha=\frac{1}{\left(x_{2}-x_{1}\right)} \cdot \ln \left(\frac{U_{1}}{U_{2}}\right)
$$

where: $U_{1}$ and $U_{2}$ - the voltage at the terminals at points hydrophone measurements.

In experiments with liquid-handling technology dispersed mixture (water-plant material) found that ultrasound attenuation value is $2.3 \mathrm{~cm}^{-1}$. This attenuation does not depend on the content of the dispersed phase (plant material) in the mixture and the operating frequency ultrasound equipment.

Based on the peak value depends on the axis sound pressure ultrasound transducer:

$$
P(x)=P(0) \cdot e^{-\alpha \cdot x},
$$

You can build a dimensionless change of coordinates of pressure measurements (Fig. 3):

$$
\bar{P}(x)=\frac{P(x)}{P(0)}=e^{-\alpha \cdot x} .
$$

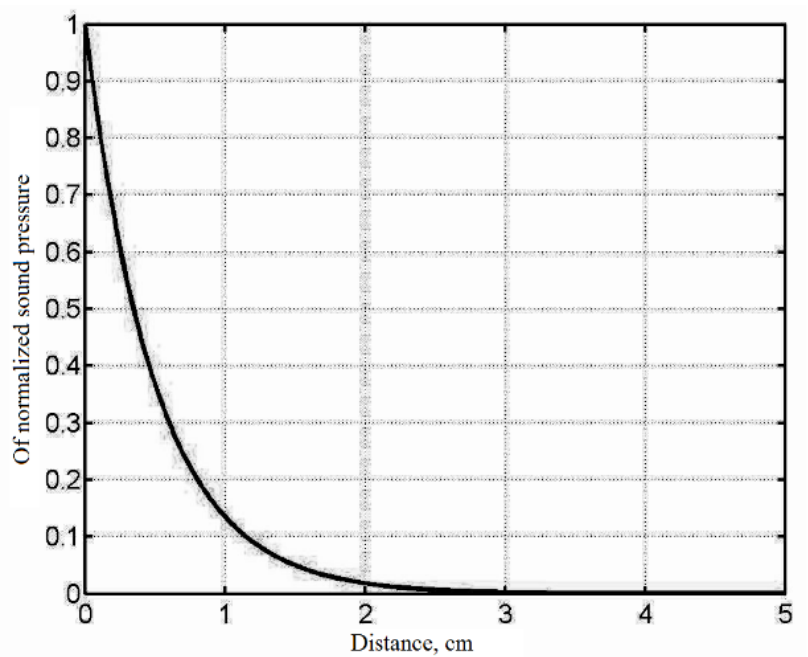

Fig. 3. Dependence of normalized sound pressure on distance from the source of ultrasound.

From the resulting dependence can be noted that the most significant change in sound pressure observed at a distance of $10 \mathrm{~mm}$ from the radiating surface, which is of the order of $20 \mathrm{~dB}$. Then change the shape of the sound field of distance is no longer significant. Thus, the measurement results in the technological mix and the water will vary by the amount of the same order.

Distribution of sound pressure and front acoustic wave in space can be described using the diagram of [27]. This ultrasound transducer can be viewed as a piston mounted in an infinite baffle.

Diagram of the piston in an infinite baffle in polar coordinates can be calculated for the potential velocity of the formula:

$$
\Psi(\theta)=\frac{2 \cdot J_{1}(k \cdot a \cdot \sin (\theta))}{k \cdot a \cdot \sin (\theta)},
$$

where $J_{1}$ - bessel function; $k$-wave number; $a$-the radius of the piston; $\theta-$ the polar angle.

Due to the fact that the potential speed and amplitude of the sound pressure related by:

$$
P=\rho \cdot \frac{\partial \Psi}{\partial t}+\text { const },
$$

where: $\rho$ - density of the liquid.

For radiation pattern can be seen on the front of the form of acoustic waves.

Analysis of the radiation pattern of high-cavitator (radius stroke of $10 \mathrm{~mm}$, the operating frequency of $22 \mathrm{kHz}$ ) experimental setup (Fig. 4), the resulting estimated equation (6) shows that the shape of almost spherical, hence, can be considered that of high-cavitator barely has designed properties.

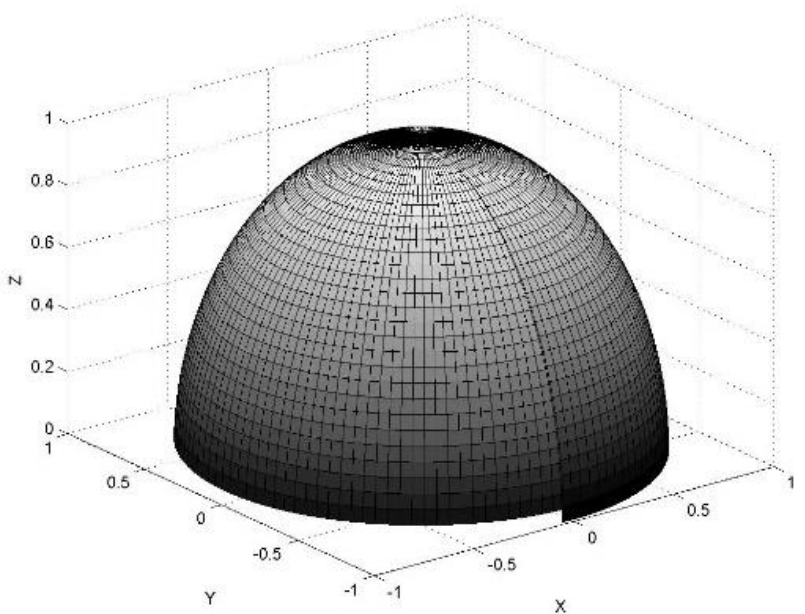

Fig. 4. Diagram of high amplitude cavitator (plane radiation lies in XOY).

It should be noted that, in general, are the considerations are valid only for the remote zone, which lies at a distance of more than the wavelength of the radiating surface-drive converter. In the near field pattern of distribution of sound field is more complicated because of interference phenomena.

The effectiveness of the ultrasound drive technological installations, in terms of converting mechanical energy into acoustic, can be measured by the impedance of radiation [26] as follows:

$$
Z=\frac{F}{V},
$$


where: $F$ - reaction force environment, $V$ - the amplitude of vibrational velocity cavitator working surface.

In general, the radiation impedance complex value is represented as:

$$
\begin{aligned}
& Z=\rho \cdot c \cdot \pi \cdot a^{2} \cdot \\
& \left(1-\frac{2 \cdot J_{1}(2 \cdot k \cdot a)}{2 \cdot k \cdot a}+j \cdot \frac{2 \cdot S_{1}(2 \cdot k \cdot a)}{2 \cdot k \cdot a}\right),
\end{aligned}
$$

where: $S_{1}(2 \cdot k \cdot a)$-struve function, $J_{1}(2 \cdot k \cdot a)-$ Bessel function.

This represents the active part of the impedance of the energy transmitted in the far zone converter, a reactive component reflects the energy spent on weight fluctuations attached liquid.

For cavitator of high-operating frequency of $22 \mathrm{kHz}$ (Fig. 5) reactive component of impedance of radiation can be comparable in magnitude with the active component.

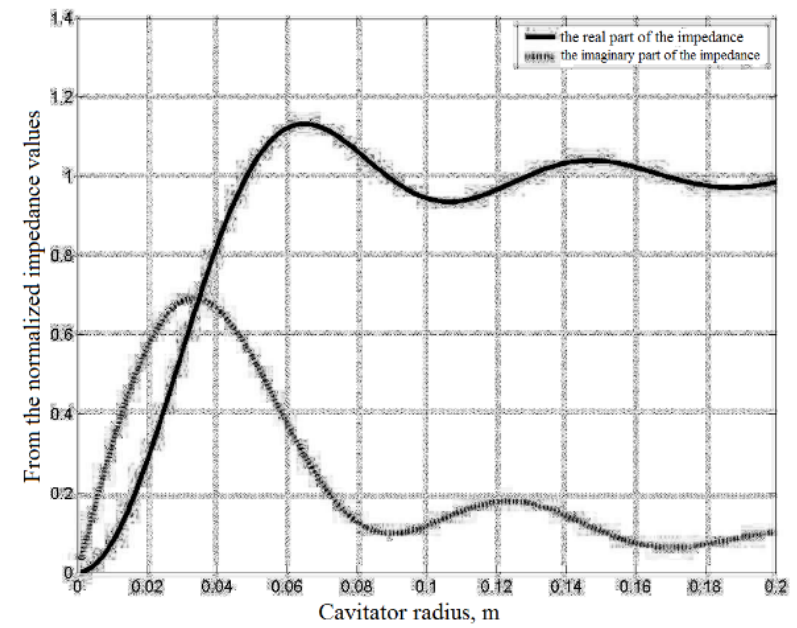

Fig. 5. From the normalized value components of radiation impedance high amplitude cavitator

It can be assumed that at the radiating surface of high-intensity acoustic cavitator arise due to the current value of the associated mass of liquid.

Experimental verification showed that the power consumption of 130 watts, the acoustic field of highcavitator a liquid-medium dispersed quickly fades in the distance from the radiating surface and at a distance of 10 $\mathrm{mm}$ at the level of noise that is consistent with the data of Fig. 3.

Therefore, the processing of such environments may be only a small volume and close proximity to the radiating surface cavitator.

Similar drives with a transformer speed and low emitting area impractical to use in manufacturing processes associated with the processing of liquiddispersed environments, including extraction, dispersion and so on.

The ultrasound small-amplitude cavitator mounted on the wall or bottom of technological capacity. The operating frequency of about $44 \mathrm{kHz}, 50 \mathrm{~mm}$ diameter radiator. Diagram of this over-converter (Fig. 6) is calculated by equation (6).

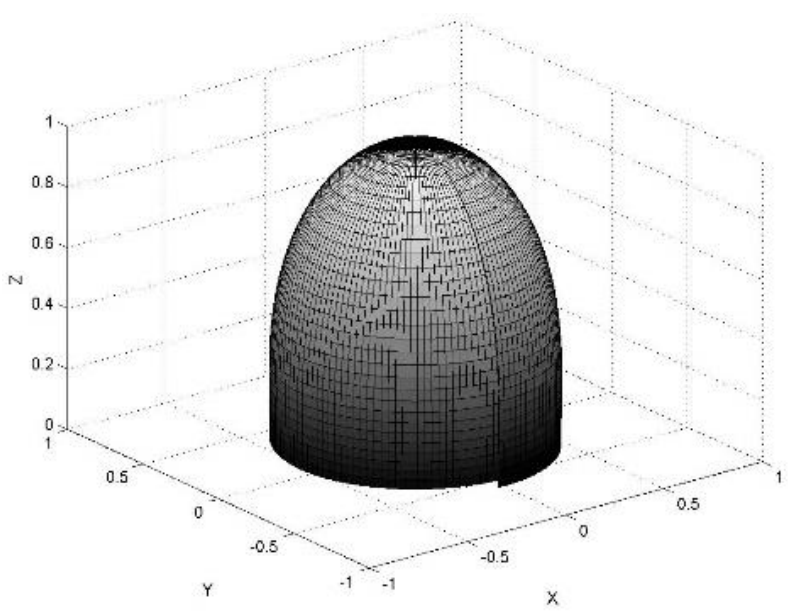

Fig. 6. Diagram of small amplitude cavitator.

Compared with of high-cavitator (Fig. 4) pattern has become more elongated in the direction toward the light.

Thus, a drive-converter has a designed properties that allow intensive process manufacturing environment in the direction of the axis of radiation.

The value of radiation resistance for small-amplitude cavitator has a significant active component of the reactive impedance (Fig. 7).

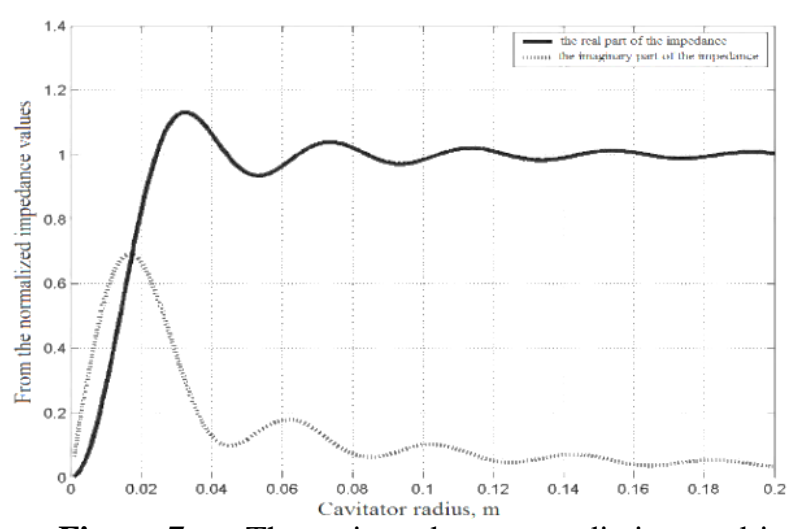

Fig. 7. The impedance radiation drive smallamplitude converter.

Thus, the cost of energy ultrasound cavitation field on the formation of much larger compared to of highcavitator.

Experimental study of distribution to smallamplitude sound pressure cavitator (Fig. 8 and Fig. 9) confirming theoretical conclusions [18].

Thus, in order to improve the ultrasound processing of liquid-dispersed environments should be used in the design of small-amplitude cavitator.

Experimental study of distribution of ultrasound cavitation field in a cylindrical chamber was performed at a frequency of $33 \mathrm{kHz}$, power 140 watts. However, note was taken analytically calculated distribution of sound pressure [28, 29], which indicates that the excitation of radial bending vibrations corresponding fashion in the center of the cross section of the chamber should expect a reduction in sound pressure and, therefore, minimal cavitation (Fig. 10). 


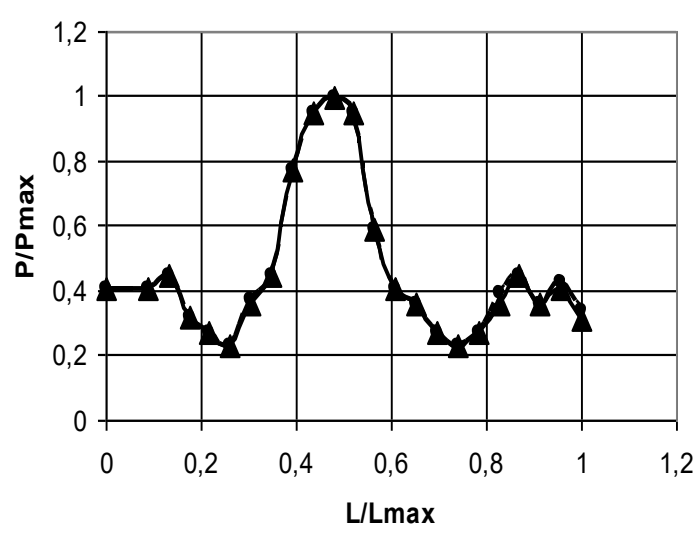

Fig. 8. Distribution of relative sound pressure to open the cavitation chamber driven radiator at bottom surface (length).

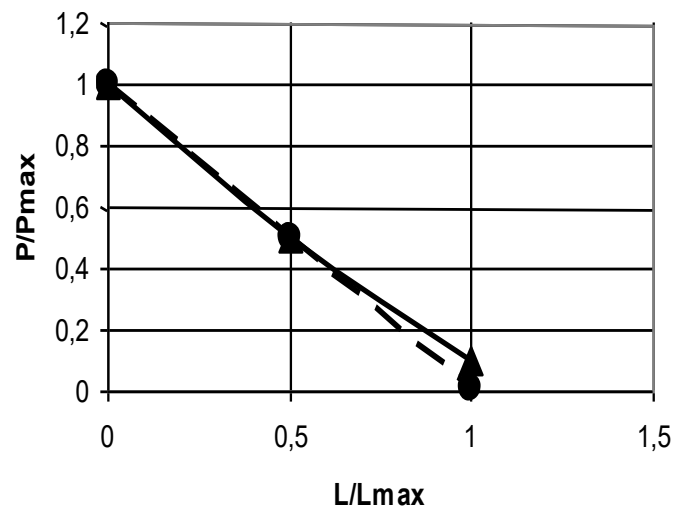

Fig. 9. Distribution of relative sound pressure to open the cavitation chamber driven radiator bottom surface to the depth in the direction opposite the radiating surface.

However, this level due to the effect of concentration of power in the chamber with a cylindrical inner surface of the profile will be higher than in the case of cavitation chamber with flat surfaces.

If the excitement in cross-section tubes cavitation chamber purely radial oscillations of ultrasound energy concentrated along the central axis of the camera that achieves high values of intensity ultrasound energy (Fig. 11).

The results of the pilot study changes in sound pressure between axis actuators, radiators confirm analytical, when excited radial bending vibrations cylindrical surface cavitation chamber pressure drop occurs in the central part (Fig. 12).

When processing dispersed technology environment (water and plant material), there is almost 10 fold drop in pressure in the central chamber, indicating that power the essential properties of the medium. And found that the rate of absorption of ultrasound energy is substantially dependent on the concentration of plant material within its industrial feasibility (15 ... 30\%).

The inner surface cavitation chamber observed maximum sound pressure level and therefore maximum cavitation activity that could adversely affect the erosion resistance of the surface of the camera, but in this area will ensure maximum effectiveness cavitation effects on the organic structure.
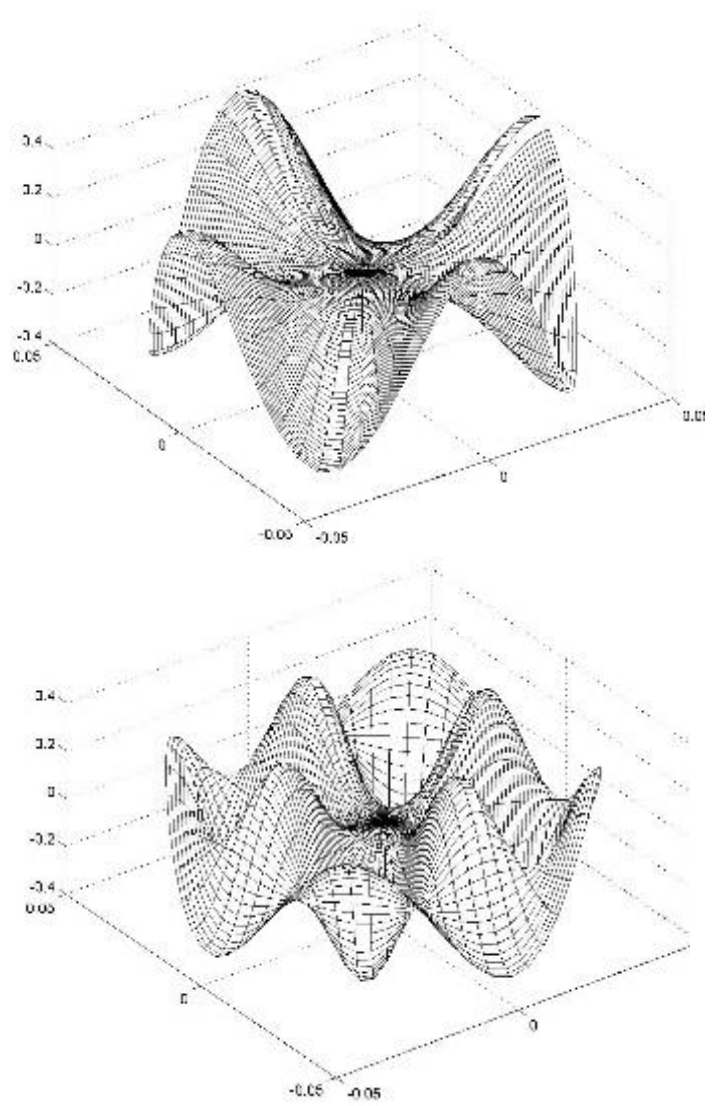

Fig. 10. Form ultrasound field in a cylindrical chamber at excitation radial bending vibrations of surface.
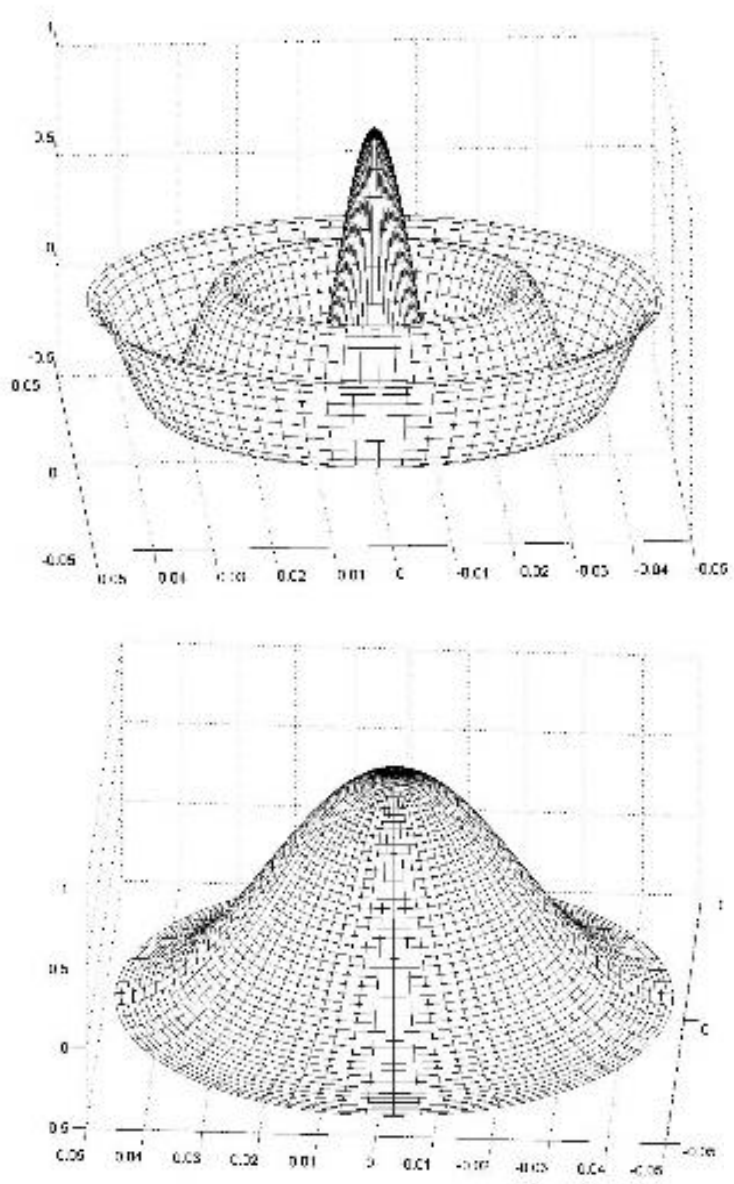

Fig. 11. Form ultrasound field in cylindrical chamber with excitation of radial oscillations of different modes. 


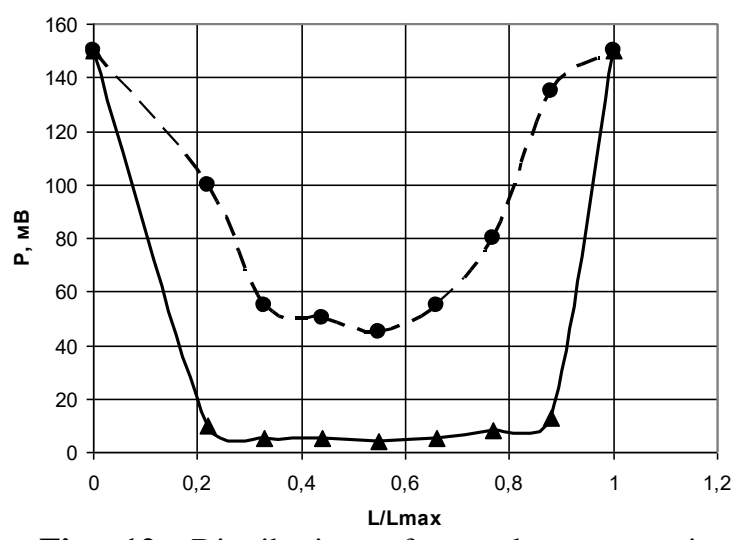

Fig. 12. Distribution of sound pressure in the cylindrical cavitation chamber in axle drives emitters.

Thus, the use of technological equipment for processing of liquid-dispersion process fluids cylindrical cavitation chamber with radial bending vibrations need to be constructive means to separate the ineffective with cavitation point of view, the central part of the chamber and ensure passage of the mixture through a zone of maximum cavitation activity, ie near the inner the surface of the cylindrical chamber.

When calculating cylindrical chamber at high-profile radial surface fluctuations can not protect against cavitation erosion of the inner surface of the chamber and get maximum cavitation activity in the area of the central axis of the camera. This focus cylindrical surface properties ensure the achievement of considerable intensity ultrasound energy. When using this option in camera production equipment needed will only flow of process fluid along the central cylindrical cavitation chamber.

Experimentally, the law of distribution of ultrasound field in clean water and liquid-dispersed environment remains almost unchanged (Fig. 13).

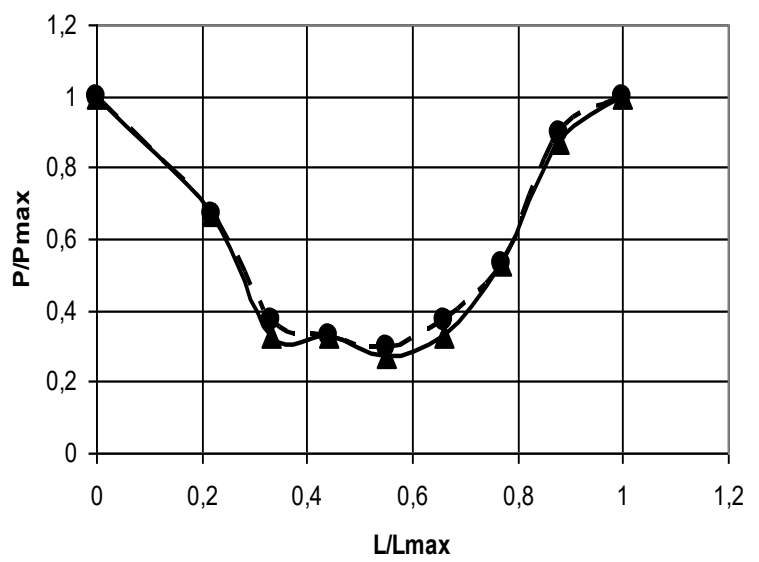

Fig. 13. Distribution of relative sound pressure cavitation in a cylindrical chamber with prepositionsemitters for creating surface.

The results of the measurement of sound pressure depth model standards cylindrical cavitation chamber (Fig. 14) indicate that the maximum value observed frontdrive transmitter and gradually fades with distance from it. This dependence indicates the presence of bending vibrations along the length of the cylindrical surface of the chamber.

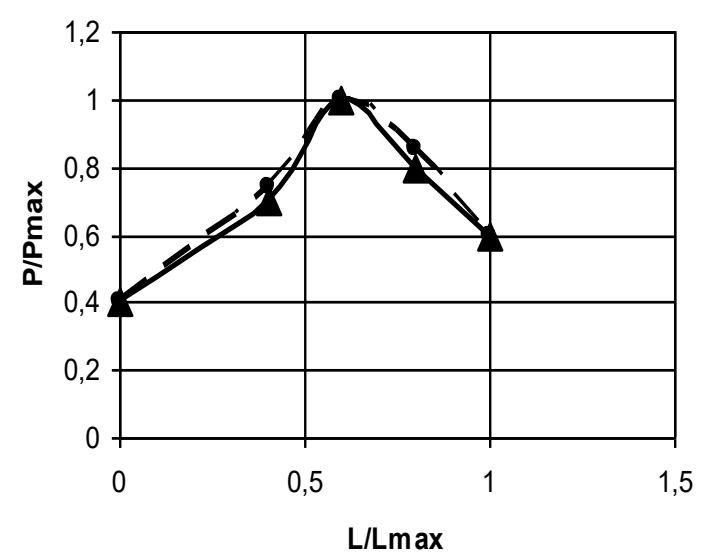

Fig. 14. The law changes the relative depth of sound pressure cylinder cavitation chamber of pretexts-emitters for creating surface.

Thus, in the case of cavitation in the technological equipment of several sections drives emitters to ensure a minimum mutual influence emitters, they must be set on creating a surface of the chamber should be at a distance of wavelength of elastic waves and connected to a generator of ultrasound vibrations parallel and in phase.

In the case of structural separation zone of high cavitation activity in the volume of the cylindrical chamber, investigates, and installs additional camera alignments in the cylindrical tube. For the case of excitation radial bending vibrations surface of the chamber, the pipe should have a diameter equal to the diameter of the line that passes through the wave antinodes strain, established in the technological mix.

For the case of surface excitation radial oscillations Camera - separate the central part of the chamber and have a diameter equal to the line that passes through the nodal points of the wave deformation, established.

The use of the auxiliary pipe of an accidental size will lead to the destruction of the sound field in the cell and, therefore, changes the distribution of sound pressure (Fig. 15).

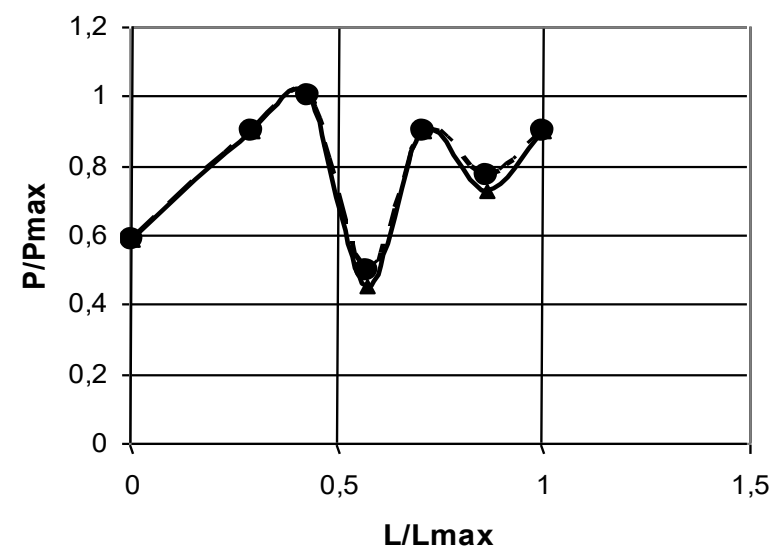

Fig. 15. Distribution of relative sound pressure cavitation in a cylindrical chamber with an auxiliary pipe (the axis drives emitters).

\section{Conclusions}

1. The analysis of existing research methods cavitation ultrasound field area. 
2. The use of acoustic measurement method using hydrophones cavitation configuration allows to explore the area and assess the intensity of the cavitation process in liquid-dispersed technology environment.

3. Experimental studies suggest significant opportunities absorbing liquid mixture of plant material provided their concentrations within $15 . . .30 \%$.

4. Researched types of high-profile occasions emitters allow for quality cavitation processing the mixture only at a distance of $30 \mathrm{~mm}$ from the surface of radiation that must be considered when creating technological equipment for processing of liquiddispersed environments.

5. Experimentally verified the identity of law ultrasound field distribution in the water and in the technological mix the light fading, and thus for designing appropriate technological equipment known to be used in the field of ultrasound cavitation technique.

\section{References}

1. Luhovskoy A., Chuhraev N. (2007). Ultrasound cavitation in modern technologies. Kyiv. Publishing and Printing Center "Kyiv University". 244.

2. Kysylev E. (2003). Intensification of processes of machining using ultrasound energy field. Ulyanovsk: Ulstu. 186.

3. Hmelev V. (2010). Application peak intensity ultrasound in the industry. Biysk: Publishing House of ALT. state. Sc. University Press. 203.

4. Fedotkyn I. (2007). Physical and mathematical foundations of intensification of processes and equipment for food and chemical technology. Kyshenev: Shtyyntsa, 18.

5. Lugovskiy A. F. (2010). Physical model of ultrasound cavitation extracting pectin from recycled plant material/ Bulletin of the National Technical University of Ukraine "Kyiv Polytechnic Institute" series "Chemical engineering, environment and resources." №1 (5). 25-30.

6. Elpiner I. (2009). Ultrasound. Physico-chemical and biological action. Moscow. Fizmatgiz. 420.

7. Knapp R. (2014). Cavitation. R. Knapp, J. Daly, F. Hamm. Moscow. Mir. 668.

8. Lyashok A. Yahno O. (2013). Energy Lugovskoy model of ultrasound spray in a thin layer. MOTROL.Commission of Motorization and Energetics in Agriculture. Vol. 15. №5, 91-97.

9. Lukyanchenko M., Jalal A., Strubalin A. (2013). Influence of technological parameters on the strength of various types of binders with ultrasound treatment vodotverdyh suspensions. MOTROL. Commission of Motorization and Energetics in Agriculture. Vol. 15, №5, 17-22.

10. Lugovskoy A. F. (2007). Improving the efficiency of ultrasound cavitation cleaning baths small volume. A.F. Lugovskoy, A.V. Movchanyuk, V.I. Chorny, M.F. Omelich, I. N. Bernik. Promyslova gidravlika i pneumatics. № 1 (15). 40-43.

11. Sankin G. N. (2005). Force acting on the cylinder with the ultrasound cavitation. G.N. Sankin, N.V. Lesser. Technical Physics. Vol. 75. Issue. 7. P. 101-105.
Bibliogr.

12. Bernik I. N. (2009). Research ultrasound field parameters in the process of hydrolysis-cavitation ekstratsiyi pectin. I.M. Bernik, A.F. Lugovskiy, A.V. Movchanyuk, A.V. Laszok. Proceedings of the National Technical University of Ukraine "Kyiv Polytechnic Institute". A series of engineering. №57. 82-87.

13. Lugovskoy A. F. (2007). Ultrasound cavitation in modern technologies. Kyiv. Vidavnicho poligrafichnycenter "Kiev The University". 244: Il, pl. Bibliogr.: 229243. ISBN 966-594-927-6.

\section{Список літератури}

1. Луховська А. М, Чухраєва Н. О. Ультразвукова кавітація в сучасних технологіях. Київ. Видавничополіграфічний центр "Київський університет". 2007. 244 c.

2. Кисельов 6 . A. Інтенсифікація процесів обробки за допомогою енергетичного поля ультразвуку. Ульяновськ: УльСТУ. 2003. 186 с.

3. Hmelev $V$. Application peak intensity ultrasound in the industry. Biysk: Publishing House of ALT. state. Sc. University Press. 2010. 203 p.

4. Fedotkyn I. Physical and mathematical foundations of intensification of processes and equipment for food and chemical technology. Kyshenev: Shtyyntsa, 18. 2007.

5. Луговський $A$. $Ф$. Фізична модель ультразвукової кавітації, що витягує пектин 3 переробленої рослинної сировини. Вісник Національного технічного університету України «Київський політехнічний інститут», серія «Хімічна інженерія, середовище та ресурси». №1 (5). 2010. C. 25-30.

6. Elpiner I. Ultrasound. Physico-chemical and biological action. Moscow. Fizmatgiz. 2009. 420 p.

7. Knapp R. Cavitation. Moscow. Mir. 2014. 668 c.

8. Lyashok A. Yahno O. Energy Lugovskoy model of ultrasound spray in a thin layer. MOTROL.Commission of Motorization and Energetics in Agriculture. Vol. 15. №5, 2013. P. 91-97.

9. Lukyanchenko M., Jalal A., Strubalin A. Influence of technological parameters on the strength of various types of binders with ultrasound treatment vodotverdyh suspensions. MOTROL. Commission of Motorization and Energetics in Agriculture. Vol. 15, №5, 2013. P. 17-22.

10. Луговський $А$. Ф. Підвищення ефективності ультразвукового очищення кавітаційних ванн невеликого обсягу. Промислова гідравліка та пневматика. № 1 (15). 2007. С. 40-43.

11. Санкін Г. Н. Сила, що діє на циліндр 3 ультразвуковою кавітацією. Технічна фізика. Вип. 75. Випуск. 7. 2005. С. 101-105.

12. Берник I. H. Дослідження параметрів ультразвукового поля в процесі гідроліз-кавітаційної екстракції пектину. Праці Національного технічного університету України «Київський політехнічний інститут». Серія техніки. №57. 2009. С. 82-87.

13. Луговський $A$. Ф. Ультразвукова кавітація в сучасних технологіях. Київ. Видавничий поліграфічний центр "Київський університет". 244 с.: 
Іл, пл. 2007. Бібліогр.: С. 229-243. ISBN 966-594-9276.

\section{ДОСЛІДЖЕННЯ ПАРАМЕТРІВ УЛЬТРАЗВУКОВОГО ОБРОБЛЮВАЛЬНОГО УСТАТКУВАННЯ, ПОШИРЕНОГО В ТЕХНОЛОГІЧНОМУ СЕРЕДОВИЩІ I. Н. Берник}

Анотація. Ефективне використання ультразвуку в конкретних виробничих процесах за рахунок впливу коливань навколишнього середовища, що проявляються у фізичному та хімічному впливі та їх взаємодії. Найбільш успішним $є$ використання ультразвукової кавітаційної обробки рідких та рідкодисперсних середовищ, оскільки вони ефективно реалізували механізм концентрації звукової хвилі в умовах високої щільності низької щільності, що викликано утворенням, розвитком та залякуванням кавітаційних бульбашок. Дослідження впливу кавітації на хімічні процеси в рідині, ерозійного ефекту акустичної кавітації, акустичної кавітації, дії на біологічні об’єкти в природі та інтенсивності акустичного шуму, що супроводжує кавітацію, показали, що методи вимірювання параметрів акустичного поля можна розділити на прямі та непрямі. Прямі методи безпосередньо вимірюють параметри процесу кавітації, такі як вимірювання тиску, що виникає при забиванні кавітаційних бульбашок. Для непрямих методів визначається технологічний чи фізичний ефект ультразвукової кавітації. Аналіз існуючих досліджень встановив, що найбільш перспективний метод конфігурації вимірювань та напруженості акустичної кавітації в полі кавітації реалізується за допомогою гідрофонів. Вимірювання значень звукового тиску проводили за допомогою вимірювальних гідрофонів на основі п'єзокераміки, в результаті чого на кришках п'єзоелемента з'являється різниця потенціалів гідрофона, значення якого пропорційно звуковому тиску. Вимірюючи величину напруги, пропорційну звуковому тиску, проводили значення вольтметрів рм в результаті вимірюваного напруги, пропорційного тиску не тільки звуку, але і інтенсивності ультразвукових коливань. Основні аналітичні залежності для визначення звукового тиску, ультразвукових коливань інтенсивності, радіаційного імпедансу дали змогу скласти графік, що показує технології обробки кавітації. Експериментально підтверджено тотожність закону розподілу ультразвукового поля у воді та в технологічній суміші 3 урахуванням його вимирання. Дослідницькі резонансні пускачі встановили випромінювачі, які забезпечують якісну кавітаційну очисну суміш можлива лише на певній відстані від випромінювання. Врахування умов створення технологічного обладнання дає змогу покращити параметри кавітаційної обробки рідкодисперсних середовищ шляхом мінімізації витрат на енергію.

Ключові слова: дослідження, параметр, обладнання, технологічне середовище.

\section{ИССЛЕДОВАНИЕ ПАРАМЕТРОВ \\ УЛЬТРАЗВУКОВОГО ОБРАБАТЫВАЮЩЕГО \\ ОБОРУДОВАНИЯ, РАСПРОСТРАНЕННОГО \\ В ТЕХНОЛОГИЧЕСКОЙ СРЕДЕ \\ И. Н. Берник}

Аннотация. Эффективное использование ультразвука в конкретных производственных процессах за счет воздействия колебаний окружающей среды, проявляющихся в физическом и химическом воздействии и их взаимодействия. Наиболее успешным является использование ультразвуковой кавитационной обработки жидких и рідкодисперсних сред, поскольку они эффективно реализовали механизм концентрации звуковой волны в условиях высокой плотности низкой плотности, что вызвано образованием, развитием и запугиванием кавитационных пузырьков. Исследование влияния кавитации на химические процессы в жидкости, эрозионного эффекта акустической кавитации, акустической кавитации, воздействия на биологические объекты в природе и интенсивности акустического шума, что сопровождает кавитацию, показали, что методы измерения параметров акустического поля можно разделить на прямые и косвенные. Прямые методы непосредственно измеряют параметры процесса кавитации, такие как измерение давления, возникающего при забивке кавитационных пузырьков. Для косвенных методов определяется технологический или физический эффект ультразвуковой кавитации. Анализ существующих исследований установил, что наиболее перспективный метод конфигурации измерений и напряженности акустической кавитации в поле кавитации реализуется с помощью гідрофонів. Измерения значений звукового давления проводили с помощью измерительных гідрофонів на основе пьезокерамики, в результате чего на крышках пьезоэлемента появляется разность потенциалов гидрофона, значение которого пропорционально звуковому давлению. Измеряя величину напряжения, пропорциональное звуковому давлению, проводили значения вольтметров рм в результате измеряемого напряжения, пропорционального давления не только звука, но и интенсивности ультразвуковых колебаний. Основные аналитические зависимости для определения звукового давления, ультразвуковых колебаний интенсивности радиационного импеданса позволили составить график, показывающий технологии обработки кавитации. Экспериментально подтверждено тождество закона распределения ультразвукового поля в воде и в технологической смеси с учетом его вымирания. Исследовательские резонансные пускатели установили излучатели, которые обеспечивают качественную кавитационная очистительную смесь возможна только на определенном расстоянии от излучения. Учет условий создания технологического оборудования дает возможность улучшить параметры кавитационной обработки рідкодисперсних сред путем минимизации затрат на энергию.

Ключевые слова: исследование, параметр, оборудование, технологическую среду. 
I. N. Bernyk ORCID 0000-0003-3754-4186. 